研究論文 歯付ベルト心線の曲率

\author{
飯塚 博 ${ }^{* 1}$ ・堤 慎哉 ${ }^{* 1} \cdot$ 渡辺 一実*1 \\ 真下 智司 ${ }^{* 2} \cdot$ 大迫 信隆 ${ }^{* 2}$
}

\title{
CURVATURE OF SYNCHRONOUS BELT CORDS
}

\author{
Hiroshi IIZUKA, Shinya TSUTSUMI, Kazumi WATANABE (Department of Mechanical Engineering, \\ Yamagata University, Jonan 4-3-16, Yonezawa 992, Japan), Satoshi MASHIMO and Nobutaka \\ OHSAKO (Mitsuboshi Belting LTD., Hamazoe-dori 4-1-21, Nagata-ku, Kobe 653, Japan)
}

The amount of curvature of synchronous belt cords was investigated to understand the fatigue failure mechanism of synchronous belts. At the first step, the curvatures of cords were measured under various mating conditions of belts and pulleys. Then, we analysed the amounts of curvature using a simple mechanical model. The belts used in this study were round-tooth (STPD) with $8 \mathrm{~mm}$ tooth pitch for high torque drives of automotive engines. The cords were constructed from eleven stranded glass filaments. One stranded glass filament was made of 600 glass fibers. The processing compound of the cords was RFL.

The distributions of curvature were measured along the belt axis. Though the distributions were different between driving and driven sides, the maximum amounts of curvature were almost equal at the both sides. Moreover, the experimental results clearly showed that the maximum amounts of curvature were almost directly proportional to the belt tight side tension, and were inversely proportional to the outside diameter of pulley.

We then proposed a simple mechanical model to explain the experimental results. The effects of tight side tension and distributed loading at the working flank were considered in the model. The analytical results succesfully explained the experimental results.

(Received on November 2, 1995)

Key word: Curvature, Synchronous belt, Cord, Fafigue failure, Pulley, Tooth pitch, Stranded glass filament, Tight side tension

\section{1. 緒言}

歯付ベルトは抗張体である心線, ゴム, 而摩 耗性を考慮した歯布，そして各界面で使用され る接着剤からなるゴム系複合材料 $(\mathrm{FRR})^{1)}$ であ る.この FRR は現在, ベルト, タイヤ, ホース のような, 大変形を許容しなければならない機 械要素に広く用いられている.しかしながら,
FRR の構成要素単体における力学的挙動でさ えかなり複雑であるため2 4), 大変形を伴う FRR の力学的性質についてはまだ解明できて いない点が多いのが現状である ${ }^{5,6)}$. 更に, 実際 にFRR を機械要素として使用する際には, 温 度や水分などの環境の効果 ${ }^{1,7)}$ 破損に対して 無視できない影響を持つことが考えられる。し たがって, このような要素に対して, 疲労破壊 
の機構や寿命評価法などを検討するには, 力学 的側面 ${ }^{8,9}$ から，あるいは化学的な側面 ${ }^{7)}$ から いった多方面からのアプローチが必要になる。

一方, それら要素の破損が, 通常の使用条件 下において主にどのような要因に支配されるか を把握することは実用上重要である。すなわち， 破損に影響する一次要因は何か, そしてその他 の二次要因としてどのような因子が考えられる かを分離して考えることが, 問題を整理する上 で大切である。このような観点に立ち, 著者ら はこれまで，歯付ベルトの破損機構解明を目的 とした一連の検討を行ってきた。 そして，第 1 報 ${ }^{10)}$ では実車走行およびベルト走行疲労試験後 のベルトに生じる損傷形態の観察を行い, ベル 卜破損は通常の走行条件下では心線内部から発 生することを示した.第 2 報 ${ }^{11)}$ では, その損傷の 発生には心線に対する屈曲の繰り返しが主な要 因であることを示した，そこで，次に重要とな る点は, その屈曲, すなわち曲率の大きさがど のような因子によって決定されるかを明らかに することである.

本研究では, プーリとかみ合う際に生じる曲 率の大きさを, 広いかみ合い条件下で測定した. そして,この曲率の分布状況, およびその大き さがどの様な因子の影響を受けて決定されるか に関し，実験と解析の両面から検討した。本研 究ではとくに, ベルト張力とプーリ歯先円直径 の影響について考察した。

\section{2. 供試材および実際方法}

\section{1 供 試 材}

ベルトの変位量測定に用いた歯付ベルトは, 自動車用丸歯 STPD 形である. 使用ゴムは水素 添加ニトリルゴム, 心線は直径 $9 \mu \mathrm{m}$ のガラス 繊維 600 本を $Z$ 撚りしたストランドを更に 11 本 $\mathrm{S}$ 撚りして作製している。結束剤には RFL (レ ゾルシン・フォルマリン・樹脂ラテックス）を 使用している.

\section{2 変位量の測定}

前報 ${ }^{11)}$ に示したと同一の測定装置を用いて， ベルト各部に繰り返される変位量を測定した。 ベルト変形の可視化は,ベルト側面に $0.2 \mathrm{~mm}$ 間隔 のけがき線を付して行った. Fig.1にその側面写 真，および測定かみ合い角度 $(\phi)$ を示す。測定 はベルト 1 ピッチ内で行った. 図中に, ベルト (a)

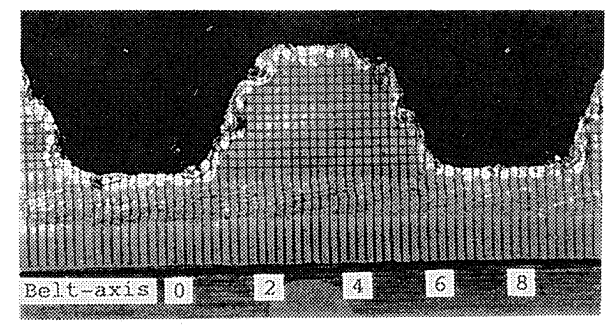

(b)

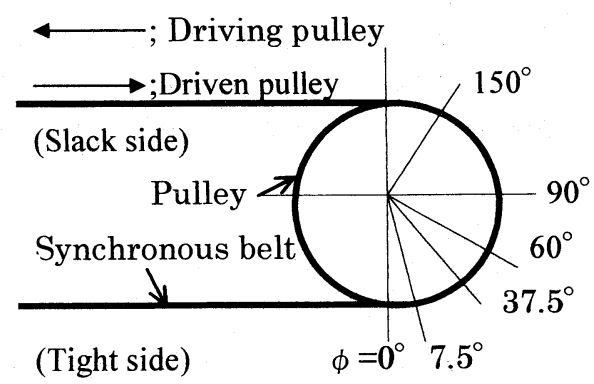

Fig.1 Measurement of curvature.

(a) belt side face with line markers,

(b) mating angles $\phi$ where measurements were performed.

軸に沿った位置（mm）を示す，以後, 測定され る曲率の分布はこの位置とともに表示する。プ ーリはステッピングモータに接続され，パソコ ンを用いて正確に回転を制御した。使用したプ ーリのピッチは $8 \mathrm{~mm}$ である. 歯数と歯先円直径 の関係を以下に示す。

18歯： $45.50 \mathrm{~mm}, \quad 24$ 歯 : $59.74 \mathrm{~mm}$

32 歯: $80.05 \mathrm{~mm}, \quad 44$ 歯: $: 110.65 \mathrm{~mm}$

60歯： $151.40 \mathrm{~mm}$.

ベルト両端には張り側とゆるみ側張力に相当す る死荷重を負荷した. 張り側張力は, 100, 200,

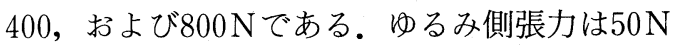
一定とした。

曲率は，プーリを $180^{\circ}$ 以上回転して安定した 嚙み合い状態を再現させた後, Fig.1(b)に示す $\phi$ の位置で, ベルト側面を写真撮影し, その写 真からけがき線の角度差を測定して算出し た ${ }^{11)}$. 


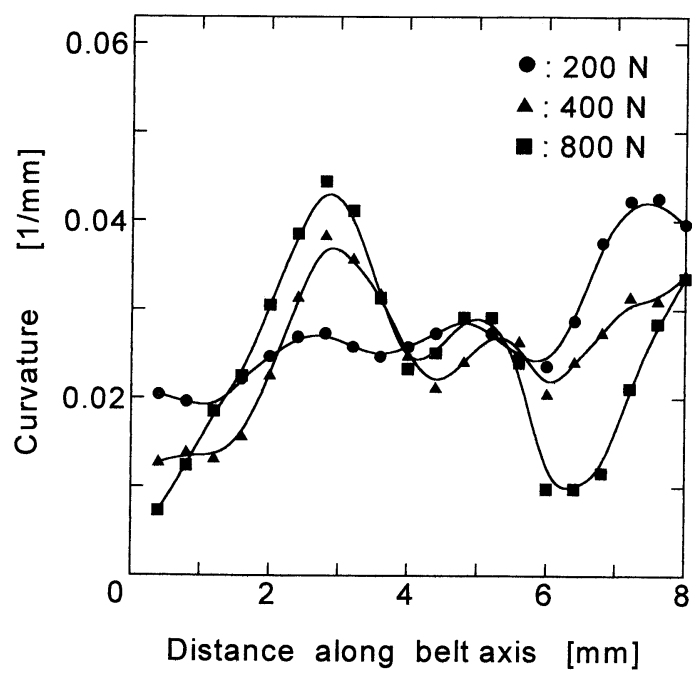

Fig.2 Effects of tight side tension on curvature around driving pulley. Mating angle $; 7.5^{\circ}$ and outside diameter of pulley $; 59.74 \mathrm{~mm}$.

\section{3. 実 験 結 果}

\section{1 ベルト張力の影響}

ベルト 1 ピッチ内に生じる最大曲率の值は, ベルトとプーリのかみ合いが始まった直後から かみ合いが終了する直前まで，ほぼ一定であっ た ${ }^{11)}$. そこで, かみ合い角度 $7.5^{\circ}$ の位置を代表例 に取り，ベルト張力の影響を調べた。

駆動側プーリ周囲で測定した曲率の分布状況 をFig.2に示す。最大值が反走行方向側の $3 \mathrm{~mm}$ 付近の位置で生じる。そして，その值は張力の 増加に伴って増加する。 また，張力が変化して も最大值の生じる位置などの基本的な分布状況 は変化しない. 更に, 走行方向側の $5 \mathrm{~mm}$ 付近に も小さな極大值が生じる．この極大值には張力 の影響はあまり現れない。

従動側プーリ周囲で測定した曲率の分布状況 を Fig.3に示す。最大值が走行方向側の $3 \mathrm{~mm}$ 付 近で生じる。そして，その值は張力の増加に伴 って増加する。また，曲率の最大值は駆動側プ ーリ周囲で生じる值とほぼ同一である。ただし， 従動側プーリ周囲では， $5 \mathrm{~mm}$ 付近に極大值はほ とんど現れない.

\section{2 プーリ歯先円直径の影響}

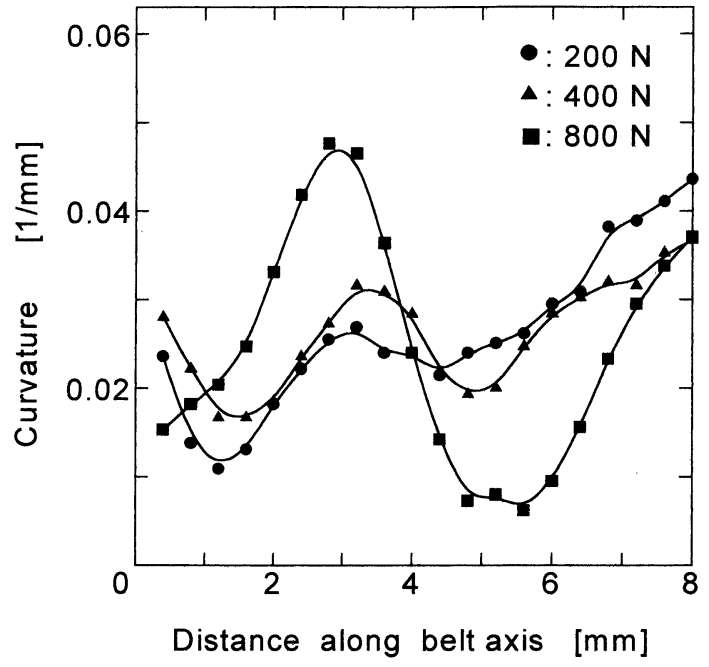

Fig.3 Effects of tight side tension on curvature around driven pulley. Mating angle $; 7.5^{\circ}$, and outside diameter of pulley $; 59.74 \mathrm{~mm}$.

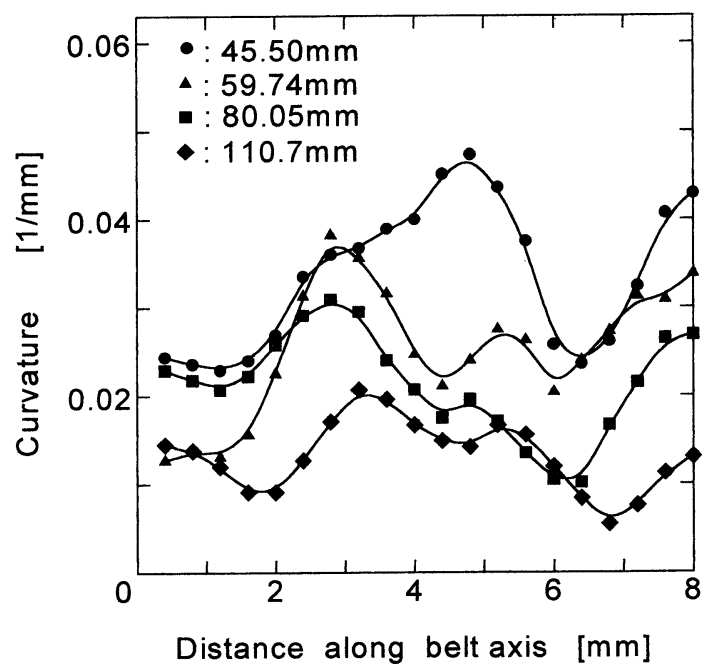

Fig.4 Effects of outside diameter of pulley on curvature around driving pulley. Tight side tension $; 400 \mathrm{~N}$ and mating angle $; 7.5^{\circ}$

プーリ歯先円直径の変化に伴う駆動側プーリ における曲率の変化を Fig.4に示す．歯先円直 径の減少に伴って曲率は増加する。また，通常 


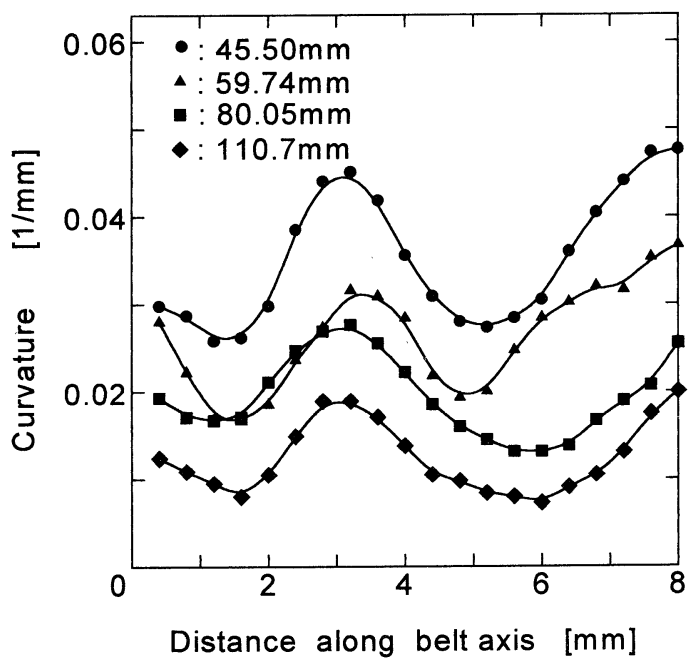

Fig.5 Effects of outside diameter of pulley on curvature around driven pulley. Tight side tension $; 400 \mathrm{~N}$ and mating angle $; 7.5^{\circ}$

使用される歯先円直径 $59.74 \mathrm{~mm}$ (歯数 24 ) 以上の プーリでは，極大值の生じる状況などの基本的 な分布に大きな変化はみられない。ただし，今 回測定した中で最も小さな歯先円直径 $45.50 \mathrm{~mm}$ のプーリでは, 曲率の大きく生じる位置が変化 する傾向がみられる。 また，このプーリではか み合い角 $\phi$ が増加すると, 広い領域で曲率が高 くなるなどの特異な分布形状がみられた。これ らの性質には，ベルト歯とプーリ歯のかみ合い 状況の変化が関係しているものと考えている.

次に，従動側プーリにおける曲率の変化を Fig.5に示す. 同様に，歯先円直径の減少に伴っ て曲率は増加し, 基本的な分布形状に大きな変 化はない. また, 歯先円直径が $45.50 \mathrm{~mm}$ のプーリ において，駆動側プーリにみられたような特異 な分布状況はみられない。

\section{4. 解 析 的 検 討}

\section{1 ベルト屈曲の力学モデル}

次に, ベルト心線に生じる曲率の值がベルト 張力やプーリの幾何学的形状とどのような関係 にあるかを検討するために，力学的な解析を行 なった.ベルトがプーリとかみ合う際のかみ合 い始めの状況を，モデル化してFig.6(a)に示す.

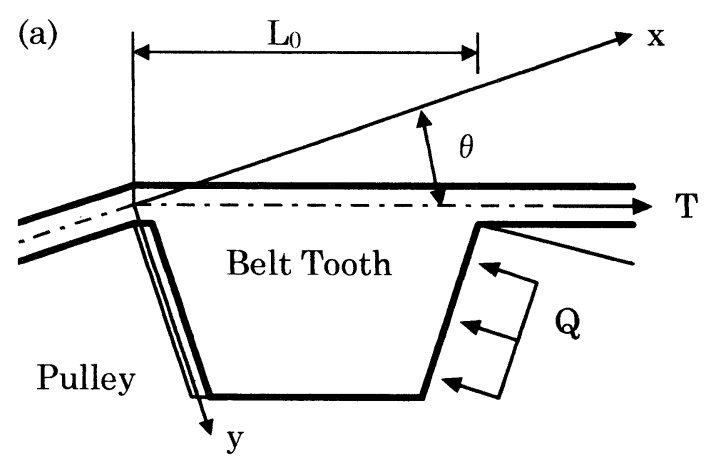

(b)

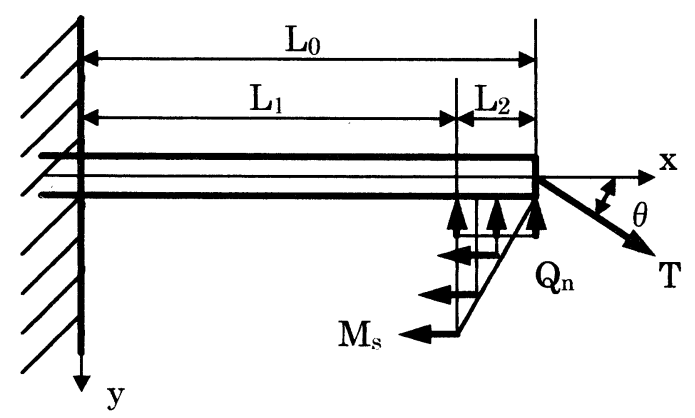

Fig.6 Analytical model of synchronous belt deformed around pulley.

本研究で使用した丸歯 STPD 型ベルトは, 歯形 状が複雑であり，更にプーリ歯底面とベルト歯 先が干渉するなど, 実際には複雑な要素を多く 含んでいる. 本研究では, 解析の第一段階とし て, 影響が大きく生じると思われるべルト張力 $\mathrm{T}$ ，およびベルト歯面とプーリ歯面の接触する 伝動面に生じる分布荷重 $\mathrm{Q}$ の効果を考慮して いる.

張力 Tは, プーリの歯溝幅 L 0 に依存した角 度 $\theta$ の方向に作用していると考える.更に, Fig. $6(\mathrm{a})$ 左端のプーリ歯先面とベルト歯底面は密 着していると仮定する。 その結果, 本問題は Fig.6(b)に示す片持ち梁のたわみ曲線を求める 問題に帰着される。ここで，Qは，梁に対して 垂直に作用する分布荷重 Qn と平行に作用する Qs に分解した.Qn はそのまま分布荷重として, また，Qs は x 軸からの距離を積算して曲げモ ーメントMs として解析に取り入れている.

梁のたわみ曲線を求める基礎式は, 


$$
\frac{d^{2} y}{d x^{2}}=-\frac{M}{E I}
$$

である。ここで，E はべルトのヤング率，I は断 面二次モーメント，そしてMは曲げモーメント である. 本解析では I は一定としている.梁を $\mathrm{x}$ 軸に沿って 2 領域に分けると, 各領域内で $\mathrm{M}$ は 以下のようになる。

$$
\begin{aligned}
x=0 & \sim L_{1} ; \\
M & =T \cos \theta(\delta-y)-T \sin \theta\left(L_{0}-x\right) \\
& -m_{1} L_{2} / 2+Q_{n} L_{2}\left(L_{1}+L_{2} / 2-x\right) \\
x= & L_{1} \sim L_{o} ; \\
M & =T \cos \theta(\delta-y)-T \sin \theta\left(L_{o}-x\right) \\
& -m_{1}\left(L_{o}-x\right)^{2} /\left(2 L_{2}\right)+Q_{n}\left(L_{o}-x\right)^{2} / 2
\end{aligned}
$$

ここで, $\delta は \mathrm{x}=\mathrm{L}_{o}$ におけるたわみ量である.ま た， $\mathrm{Q}$ は等分布していると仮定し， $\mathrm{m}_{1}$ は分布し ている曲げモーメント Ms の $\mathrm{x}=\mathrm{L}_{1}$ における值 （最大值）である.

境界条件は，

$$
\begin{aligned}
& x=0 ; \quad y=0, \quad d y / d x=0 \\
& x=L_{1} ; \quad y_{1}=y_{2}, \quad(d y / d x)_{1}=(d y / d x)_{2}
\end{aligned}
$$

である.この問題は平易な材料力学の問題とし て，容易に解くことができる ${ }^{12)}$.

結局，ベルトの曲率は次式で示すことができ る。

$$
1 / \rho=\mathrm{A}_{i} \beta^{2} \mathrm{e}^{\beta x}+\mathrm{B}_{i} \beta^{2} \mathrm{e}^{-\beta x}
$$

ここで, $\rho$ は梁の曲率半径, $\mathrm{A}_{\mathrm{i}}, \mathrm{B}_{\mathrm{i}}$ は $\mathrm{Q}_{\mathrm{n}}, \mathrm{m}_{1}$ と 幾何学的形状とから決定される定数項であり, 2 領域でそれぞれ決定される。また， $\beta=$ $(\mathrm{T} \cos \theta / \mathrm{EI})^{0.5}$ である。

\section{2 数值計算例}

数値計算をするにあたり， $\mathrm{Q}_{\mathrm{n}}$ と $\mathrm{m}_{1}$ の決定が 重要である. 本研究では, これらの值を前報 ${ }^{11} に$ おいて測定したベルト歯元のせん断ひずみの值 に基づいて算出している.すなわち，ベルト歯 元で測定されたせん断ひずみの最大值とゴムの 横弾性係数 $\mathrm{G}$ の積によってベルト歯に作用す る総せん断荷重 $\tau[\mathrm{N}]$ を算出した. 本研究では, これまでの測定範囲内で得られた以下の実験式 を用いている.

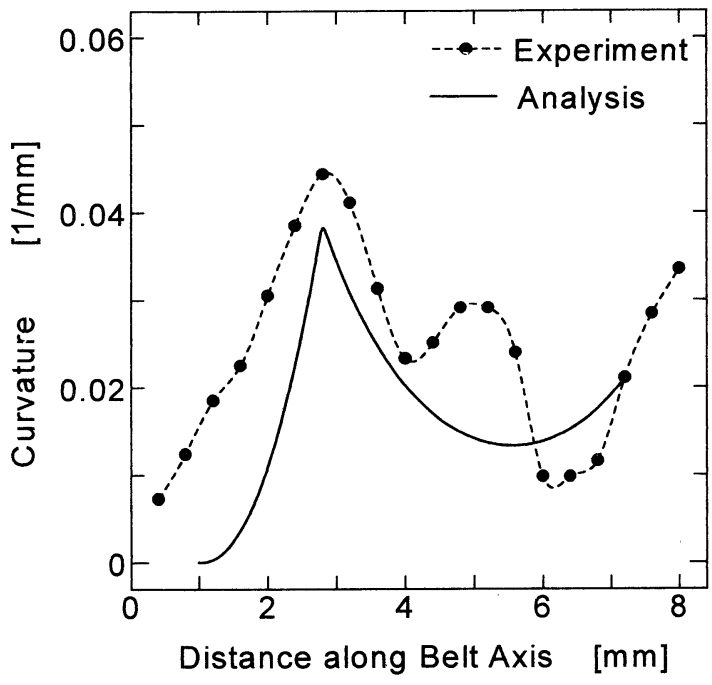

Fig.7 Comparison between experimental data and analytical result. Experimental data was obtained under driving side, $\mathrm{T} ; 800 \mathrm{~N}$, mating angle $; 7.5^{\circ}$ and outside diameter of pulley;59.74mm.

$$
\tau \approx G A_{t}\left(4 \times 10^{4} T+4.22 / R-0.12\right)
$$

(6)式において $\mathrm{T}$ は張力 $[\mathrm{N}], \mathrm{R}$ はプーリ歯先円 の半径 $[\mathrm{mm}], \mathrm{G}$ はベルト歯の横弾性係数 $[\mathrm{MPa}]$, そして $\mathrm{A}_{t}$ はベルトの幾何学形状で決 まる歯元断面積 $\left[\mathrm{mm}^{2}\right]$ である. てはその後, 伝動 面に沿う等分布荷重に置き換えている。これら の計算に際し, 弾性係数 E と G の值には, ゴム の代表的な值である $10 \mathrm{MPa}$ と $3 \mathrm{MPa}$ をそれ ぞれ使用している. また，断面二次モーメント I は実際のベルト歯高さを用いて算出してい る。

(5)式の計算結果と代表的な実験値の比較を Fig.7に示す.細部では多少の差は生じるが，全 体的な曲率の分布形状は再現されている。また, 定量的にも大きな差はなく, 実験值と解析結果 は良く一致していると考えられる，ただし，横 軸 $5 \mathrm{~mm}$ の近傍で実験結果に極大值が生じ，この 傾向は今回の解析モデルでは再現できていな い.この性質は, 断面二次モーメント I がベルト 歯の存在によってこの位置で変化することに関 係すると考えている。 
本研究の計算範囲内では, 曲率の最大值は $\mathrm{x}=\mathrm{L}_{1}$ の位置で常に生じる.そこで, 次にこの曲 率の最大值のベルト張力およびプーリ歯先円直 径依存性について検討した。曲率の最大值（1/ $\rho)_{L_{1}}$ は, (5)式に $\mathrm{x}=\mathrm{L}_{1}$ を代入することによって， 次式のように求まる。

$$
\begin{aligned}
\left(\frac{1}{\rho}\right)_{L_{1}}= & m_{1}\left\{\frac{\beta \sinh \beta L_{1} \cosh \beta L_{1}}{T \cos \theta \cosh \beta L_{o}}-\frac{\left.\left(\cosh \beta L_{2}-1\right) \cosh \beta L_{1}\right)}{T \cos \theta L_{2} \cosh \beta L_{o}}\right\} \\
& +\beta\left\{\tan \theta-\frac{Q_{n} L_{2}}{T \cos \theta}\right\}\left\{\tanh \beta L_{0} \cosh \beta L_{1}-\sinh \beta L_{1}\right\} \\
& -\frac{Q_{n}}{T \cos \theta} \frac{\left(\cosh \beta L_{2}-1\right) \cosh \beta L_{1}}{\cosh \beta L_{o}}
\end{aligned}
$$

(7)式を用いて算出した曲率のベルト張力依存 性を Fig.8に示す．計算結果は実験結果よりも やや低い值を示すが，実験結果の張力依存性と 良く一致している。 また，今回測定した張力の 範囲内では, 最大曲率の值と張力はほほ比例関 係にあることがわかる，ただし，この比例関係 から外れる傾向が, 張力のやや低い領域で現れ ている。

次に, 曲率のプーリ歯先円直径依存性を Fig. 9に示す.計算結果は実験結果の特性と良く一致 している.また，この計算結果はプーリ歯先円 直径に反比例する特性に近い。すなわち，曲率

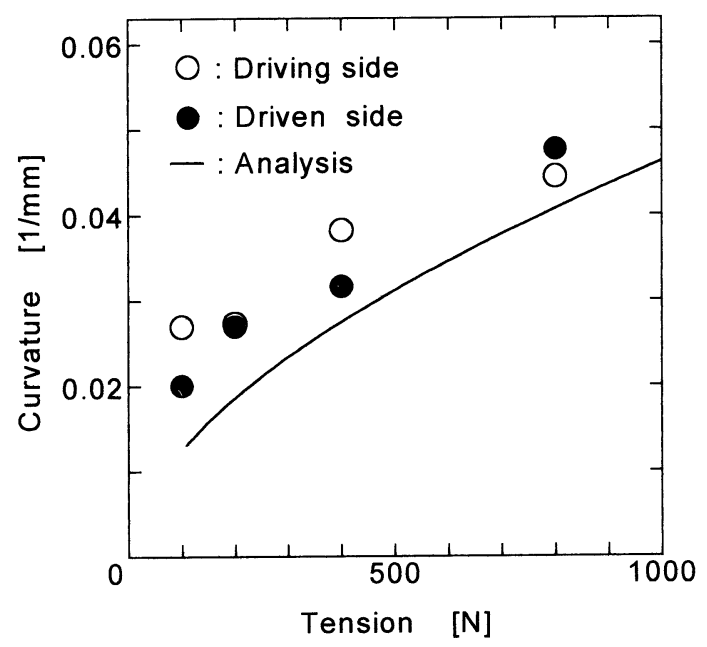

Fig.8 Relationship between curvature and belt tension. Experimental data was obtained under mating angle $; 7.5^{\circ}$ and outside diameter $; 59.74 \mathrm{~mm}$.

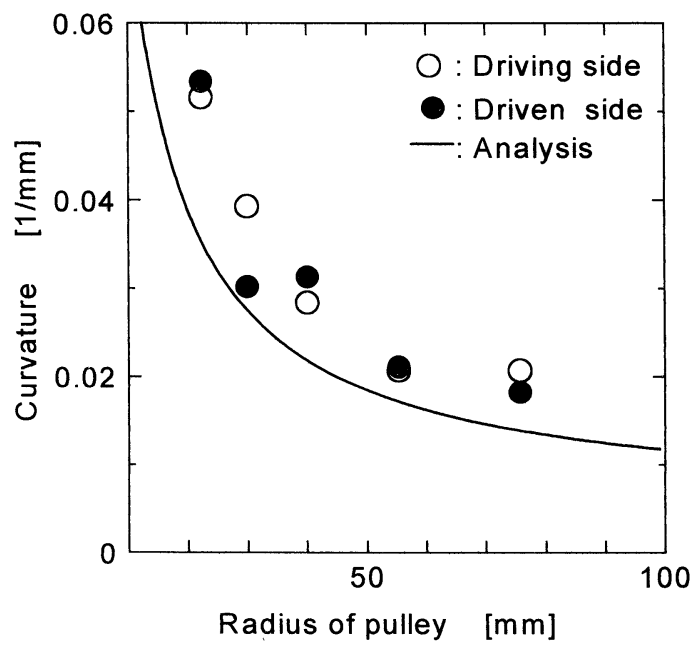

Fig.9 Relationship between curvature and outside diameter of pulley. Experimental data was obtained under $T ; 400 \mathrm{~N}$ and mating angle $; 7.5^{\circ}$

の最大值はプーリ歯先円直径にほぼ反比例する ことがわかる．以上の結果から，今回の解析結 果は，実験結果の特性を充分に説明できるもの であることがわかる。

次に，(7)式の近似式を求め，(7)式の持つ性質 についてさらに考察した。(7)式に含まれる双曲 線関数の変数 $\left(\begin{array}{ll}\beta & L_{1}\end{array}\right)$ が充分大きい条件下で は, 以下の近似式が得られる。

$$
\frac{1}{\rho}=\frac{1}{2 \cos \theta}\left\{\frac{M s}{T}\left[\beta-\frac{1}{L_{1}}\right]+\frac{Q_{n}}{T}\right\}
$$

ただし,(8)式の定量的な精度はあまり良くない。 (8)式から，曲率は（Ms/T) および $\left(\mathrm{Q}_{n} / \mathrm{T}\right)$ の 大きさに依存していることがわかる。すなわち， ベルトに生じる最大曲率值の特性には, 伝動面 で生じる分布荷重の張力およびプーリ歯先円直 径依存性が大きく影響していることがわかる.

また，今回(7)式を用いて計算した最大曲率の 值は測定值よりも多少低めの值になった。この 原因としては, ベルト歯先とプーリ歯底面の干 渉やベルト歯の複雑な幾何学形状などを考慮し ていない点，あるいはベルト歯面とプーリ歯面 の接触する伝動面の分布荷重を等分布荷重と仮 定している点が考えられる。また, 計算に使用 
した $\mathrm{E} や \mathrm{G}$ の值も良く吟味して使用していな い. 更に，実際のベルトでは歯元丸み部などで すでに大変形の領域に入っている可能性もあ り, 本研究で行ったような簡単な材料力学のモ デルでは取り扱えない問題を含んでいることも 考えられる。

\section{5. 結}

言

心線に生じる屈曲の大きさを曲率で表示し， その曲率がどのような因子の影響を受けて決定 されるかについて実験と解析の両面から検討し た. 得られた結果の要約を以下に示す.

1）心線に生じる曲率を測定した結果，1ピッ チ内に生じる曲率の最大值は, ベルト張力の 増加にほほ比例し, 更に, プーリ歯先円直径 の増加にほほ区比例して変化することがわか った。

2）ベルト屈曲の簡単な力学モデルを提案し た。その数值計算結果は, 実験によって得ら れた曲率のベルト張力依存性とプーリ歯先円 直径依存性を良く再現した。

3）ベルト心線に生じる最大屈曲の生じる位置 とその大きさには, ベルト歯面がプーリ歯面 から受ける分布荷重の特性が大きく影響する ことがわかった。

[謝辞］ベルト屈曲の力学モデルに関して, 御 議論いただきましたGöran Gerbert教授 (Chalmers University of Technology,
Sweden）に深謝致します。

\section{参 考 文 献}

1）林 毅編：複合材料工学，日科技連 (1971), P.595

2）佐藤 隆：日ゴム協誌，66，563（1993）

3) Costello, G.A. : Appi.Mech.Rev., 31, 897 (1978)

4) Hearle, J.W.S. : "Structural Mechanics of Fibers, Yarns and Fabrics", John Wiley and Sons, New York (1969)

5) Akasaka, T.: in "Textile Structural Composites", edited by Tsu-Wei Chou and Frank K Ko, Elseviel, Amsterdam (1989), p. 279

6）加部和幸, 小石正隆，赤坂 隆：日ゴム協 誌，67，192（1994）

7）福森健三：日ゴム協誌，65，445（1992）

8）小山富夫, 村上浩二, 中井 肇, 籠谷正則, 保城 武：機論 C，44，312（1978）

9）綱島貞男, 藤井 透, 北林雅之 : 機論 C, 55，1477 (1989)

10）飯塚 博, 渡辺一実, 堤 慎哉, 真下智司： 日ゴム協誌，67，714（1994）

11）飯塚 博, 渡辺一実, 堤 慎哉, 真下智司, 大迫信隆：日ゴム協誌，68，559（1995）

12）例えば, 三好敏郎, 白鳥正樹, 尾田十八： 材料力学, 実教出版（1975), p.190 